\title{
Why Does Individual Learner Perform Better than Others? Relating Students Learning Style to Academic Performance
}

\author{
Ah. Zakki Fuad \\ English Language Education Department, \\ UIN Sunan Ampel Surabaya
}

\author{
Mir'atul Khoiriyah \\ English Language Education Department, \\ UIN Sunan Ampel Surabaya
}

\author{
Maulidya Andriana \\ English Language Education Department, \\ UIN Sunan Ampel Surabaya
}

\begin{abstract}
Students learning style may give impact in students academic performance. The higher achiever or lower achiever may have their own unique learning style. In the English Teacher Education Department of UIN Sunan Ampel Surabaya, the students sometimes have higher GPA and few of them get the lower GPA. This research examine in conducting the PBI student's learning style in UINSA. Then, aim to focus on special issue which is individual learning style may give impact or not to student's academic performance and determine whether there are any significant different in learning style between lower achiever and higher achiever.Especially the students of English Teacher Education Department in 6th semester of The Faculty of Education and Teacher Training in the State of Islamic University of Sunan Ampel.The writer use quantitave data as the research design. Then, the data will be analyzed by some procedure, such as : coding, T-test analysis and reporting the data by using SPSS. The finding reveals that there was not significant correlation between student's learning style to their academic performance. May this study can help teacher and researcher later to conduct a new study that related to learning style.
\end{abstract}

\section{Keywords: learning style, academic achievement, VARK}

\section{INTRODUCTION}

Students have different unique ability and qualification to influence their academic performance especially in the colleges. One of the indicators may highlight the university student's qualification is about academic performance which is mostly measure with GPA / Grade Point Average (Cumhur Erdem, İsmail Senturk and Cem Kaan Arslan, 2007). Why there was students have higher GPA than the others? Many factors are considered as determiners of the students' GPA such as gender,previous academic performance, living place and income level of family, socialenvironment, the type and quality of the high school graduated, the high school grade point average, the score obtained from nationwide university entrance exam (OSS), time spendfor studying, learning ability and living place during the university life (Cumhur Erdem, İsmail Senturk and Cem Kaan Arslan, 2007).

Learning style has an important role for individual learner. When the individual knows his/her learning style, they will integrate it in the process of learning so they will learn more easily and fast to accept information. According to (Fleming, 1995) common learning style that students use are VARK. It defines types of learning style in terms ofthe sensory modality. There are four sensory modalities of learninghave been defined: visual, auditory, read-write andkinesthetic. Visual learners think in pictures and learn best in visual images. They depend on the instructor's or facilitator's non-verbal cues such as body language to help with understanding. Auditory learners discover information through listening and interpreting information by the means of pitch, emphasis and speed (Ldpride,n.d, 2009). Read and write learners are more prefer in word and text, for example like read and they give a simple sentences to get the point (Larry and Marie, 2005). Kinesthetic learners are learn best with and active "hands-on" approach (Ldpride,n.d, 2009.). Moreover, Learning style is about the way of students' learning and understanding information delivered by their teacher in the classroom. A learning style refers to the way people receive, process, evaluate, understand, and utilise information in learning (Battaglia, 2008).

Some factors are belief that learning style, such as gender and age can influence students learning style. According by findings from (Farkas,2003) maintained that young adult males prefer visual learning style to young adult females. 
learn best. Besides that, the researchers also collect the data of student's GPA from the questionnaire. said that males are more visual learners than females. Then, it emphasized that adult learners who use visual learning style rememberand recall information or facts faster and better than those who do not use visual learning style. It can be known that gender also has role for individual learning style. From those previous study we can know that male more visual learners than female.

The previous study only focus on GPA in different factor between gender, social environment and soon. The other one focus on adult males are focus on visual learning style in general. Thus, this research examine in conducting the PBI student's learning style in UINSA. Then, aim to focus on special issue which is individual learning style may give impact or not to student's academic performance and determine whether there are any significant different in learning style between lower achiever and higher achiever.

\section{METHOD}

\section{Research Designed}

This research design is quantitative data analysiswhich to measure the learning style of English Education Department students in $6^{\text {th }}$ semester of State Islamic University of SunanAmpel Surabaya. Besides that, for the technique of data sampling the researcher use random sampling, the purpose of using random sampling is every people in a population have the same opportunity to be a sample in this research. The researchers took 30 participant as the sample by take 10 of participant on the each semester, such as: the second, third and sixth semester. After the researchertook the sample of this research, the researchers continue to decide where and when the data will be collected. Besides that, the researchers also prepare the instrument or questionnaire for collecting the data. The researchers start to collect the data and after that the researcher continue with coding, analyzing, and reporting the data.

\section{Participants}

This The target population of this research isEnglish Education Department students in second, fourth and sixth semester of State Islamic University of Sunan Ampel Surabaya.This researchers using random sampling and the researchers will choose 30 students as the sample of this research.

\section{Instrument}

In this study, the researchers use the questionnaire from Vark Questionnaire. The questionnaire took from www.vark.com. There are some version of questionnaire that the researchers found and the researcher took Vark Questionnaire (The Younger Version) with the tittle How do I

\section{Procedure}

The questionnaire will be demonstrated during the time in the campus. The researchers gives 30 questionnaires to students. There are three semester that the researcher took. They are second, fourth and sixth semester and 10 students for each semester. The participants also write their GPA in the previous semester. Then, the researchers sum the result of the questionnaire by coding and using SPSS.

\section{FINDINGS AND DISCUSSION}

The data collection were conducted in Tarbiyah Faculty in The State Islamic University of Sunan Ampel in december. The sample of the resesarch was taken from students college of English Teacher Education Department of 30 people. The Data were carried out by T-test method with the spss aplication with significance p,0,05 to find out the learning styles that will affect the students.

The criteria that the researcher used:

1. If the significant data $\mathbf{P}>\mathbf{0 . 0 5}$, so the variable does not affect

2. If the significant data $\mathbf{P}<\mathbf{0 . 0 5}$, so the variable affect to the other variable

The Dominant Learning Style

Statistics

\begin{tabular}{|l|r|r|r|}
\hline & A & B & C \\
\hline N Valid & 30 & 30 & 29 \\
\multicolumn{1}{|c|}{ Missing } & 7 & 7 & 8 \\
Std. Deviation & .27010 & .29442 & .23686 \\
Range & .91 & 1.08 & 1.08 \\
Minimum & .55 & .67 & .58 \\
Maximum & 1.45 & 1.75 & 1.67 \\
Sum & 32.73 & 32.50 & 29.75 \\
\hline
\end{tabular}

From the T-test analysis Data that showed in the table, the researcher found the dominant learning style/ the common learning style of college student in education teacher department of The Islamic State of University Sunan Ampel is Visual learning style with the statistic data that already seen in sum point 32.73 and for Auditory learning style is 32.50 and the lower of sum is kinesthetic 29.75 , so from the thirthy respondent, they like visual learning style. 
We can see, in the learning process honestly the commong learning style that the students maybe almost like are visual and audio, it can be concluded also that the college students of English Teacher Education Department prefer to visual learning style than others. It is supported by Felder \& Spurlin (2005) that visual learners are good observer and look into detail precisely; they learn better through others demonstration, body language or expression academic performance. They do better in academic performance through writing and reading, they do not do well through listening only. (Whitman \& Schwenk 1984) Moreover, they prefer quiet study environment and tends to be alone when they studying or reading. This because they cannot concentrate if there is obstruction.(Felder Henriques, 1995). Before they do a project they will look at the purpose and overall view first so that can visualized the whole picture to make them understand better to achieve better academic performance (Felder \& Spurlin, 2005).

\section{The Average of GPA}

\section{Group Statistics}

\begin{tabular}{|c|r|r|r|r|}
\hline Gender & $\mathrm{N}$ & Mean & $\begin{array}{c}\text { Std. } \\
\text { Deviation }\end{array}$ & $\begin{array}{c}\text { Std. Error } \\
\text { Mean }\end{array}$ \\
\hline $\begin{array}{c}\text { GPA Laki-Laki } \\
\text { Perempu } \\
\text { an }\end{array}$ & 4 & 3.1025 & .20500 & .10250 \\
\hline
\end{tabular}

From the table, it shows that the average GPA of female students is 3.4, and the average GPA of male is 3.1. But, the male students have low GPA because they have less frequency than female students. So, the male students of English Education in State Islamic University of Sunan Ampel Surabaya cannot be stated that their GPA is lower than females students because their frequecy is less than female students.

\section{Correlations}

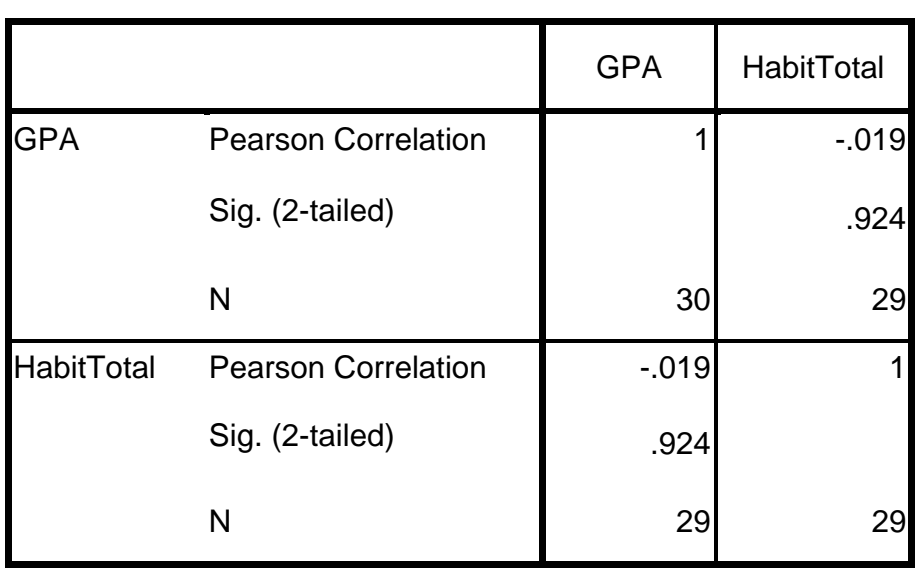

The table shows that the $\mathrm{P}=0.9(>0.05)$ it means that there is no correlation between the high GPA with the student's learning style that they used. Based on the analysis data, it can be interpreted that the student's learning style do not significantly affect to the student's GPA of 6th semester in English Education Department of State Islamic University of Sunan Ampel Surabaya.

The previous research from Keliat and friends (2016) showed that there is no any correlation between the student's learning style with the student's GPA. The student's GPA is affected by external and internal factor. The External factor can be from the family, the environtment, the learning style and the curriculum but for internal factor can be from cognitive aspects, such as : intellegence, passion, motivation, and etc.

The Correlation Between Learning Style to student's GPA 


\section{CONCLUSION}

Students with the most dominant learning style are visual learning styles with a mean age of 32.73 and lowest kinesthetic learning styles 29.75.The average GPA of male students is 3.4, and the average GPA of male is 3.1. But, the male students have low GPA because they have less frequency than female students. So, the male students of English Education in State Islamic University of Surabaya cannot be stated that their GPA is lower than students because of their frequencies is less than female students. The student's learning style does not significantly affect the semester's GPA of 6th grade in English Education Department of Islamic State University of Sunan Ampel Surabaya. Because, students' GPA can influence not only from internal factors like learning styles but the students who get high GPA can be influenced by external factors such as environtment, motivation, etc. This research has some limitation to examine. First, in types of participant of 30 sample and only took 10 participant in each semester. Second, in the types of limitation of the time, the researchers took participant from the faculty of education teacher and training, English teacher education department 2019-2020.For the teacher, in reference to the conclusion, it is recommended that the teacher can use VARK learning style (Visual,Audio,Reading and Kinesthetic) as an strategy for learning process. For future researcher, this study may help the teacher as a reference to conduct further study abou learning style.

\section{REFERENCES}

[1] Alqunayeer, Huda Suliaman and Sadia Zamir Qassim (2015). Identifying Learning Styles in EFL Classroom. International Journal of Learning and Teaching Vol. 1, No. 2, December 2015.

[2] Battaglia, M. 2008. Convenience Sampling. In Paul J. Lavrakas (Ed.), Encyclopedia of Survey Research Methods. Thousand Oaks, CA: Sage Publications, pp 149-150.

[3] Bricheno, P. \& Yomger, M. (2004). Use of learning styles. Retrieved on 9th August, 2004 from www.standarddfes.govts :Uk/thinking skills/resources.

[4] Cumhur Erdem, İsmail Senturk and Cem Kaan Arslan, (2007). Factors affecting grade point average of university students. https://www.researchgate.net/publication/228426787.

[5] Farkas, R. (2003) "Effects of traditional versus learning styles instructional methods on middle schoolstudents". The Journal of education research 97; (1), 42-51.

[6] Fleming ND. I'm different; not dumb. Modes ofpresentation (VARK) in the tertiary classroom. In:Research and Development in Higher Education,edited by Zelmer A. Proceedings of the 1995Annual Conference of the Higher Education and Research.

[7] Gilakjani, Abbas Pourhossein.2011. Visual, Auditory, Kinaesthetic Learning Styles and Their Impacts on English Language Teaching. Iran. Journal of Studies in Education.

[8] Larry, M. N., \& Marie, B. (2005). Work in progress learning styles and elearning, what is the connection?. 35th
ASEE/IEEE Frontiers in Education Conference. Unpublished presented papers.

[9] LdPride,n.d. (2009). What are learning styles? Retrieved from http://www.ldpride.net/learningstyles.MI.htm

[10] Moayyeri, Hessam. 2015. The Impact of Undergraduate Students' Learning Preferences (VARK Model) on Their Language Achievement. Iran. Journal of language teaching and research.

[11] Nafis, Hilyatun. 2016. STUDENTS' PREFERENCE OF LANGUAGE LEARNING STYLE IN ENGLISH CLASSROOM. Banda Aceh. 